\title{
PANEL DATA ANALYSIS OF RELATIONSHIP BETWEEN ECONOMIC GROWTH, FOREIGN DIRECT INVESTMENT, EXCHANGE RATE AND TRADE OPENNESS IN NEWLY INDUSTRIALIZED COUNTRIES
}

\author{
Asst. Prof. Sevilay KÜÇÜKSAKARYA (Ph.D.) * iD \\ Prof. Mustafa ÖZER (Ph.D.) *
}

\begin{abstract}
This study examines the effects of foreign direct investment, gross fixed capital formation, real exchange rate, and trade openness on economic growth in newly industrialized countries from 1982 to 2019 by using the panel ARDL method. Before estimating panel ARDL, we tested the existence of cross-sectional dependence among the countries, determining the degree of the integrations of variables by using second-generation panel unit root tests and examining the cointegration among the variables. Finally, we carry out the Dumitreuscu Hurlin causality test to determine the direction of the causal relationship between variables. The study results indicate a positive long-run relationship between economic growth and FDI, gross capital formation and real exchange rate, and a negative long-run relationship with trade openness. The study's findings have significant implications for the industrial policies that these countries should adopt to reach developed countries.
\end{abstract}

Anahtar Kelimeler: Economic Growth, Newly Industrialized Countries, Panel ARDL, Panel Unit Root Tests, Panel Cointegration Tests, Dumitrescu Hurlin Causality Test.

JEL Kodlart: C23, F43, O47

YENI SANAYİLEŞEN ÜLKELERDE EKONOMIK BÜYÜME, DOĞRUDAN YABANCI YATIRIM, DÖVİZ KURU VE TİCARİ AÇIKLIK ARASINDAKİ ILISSKININN PANEL VERİ ANALIZi

\section{ÖZET}

Bu çalışma, yeni sanayileşen ülkelerde 1982 ve 2019 yılları için doğrudan yabancı yatırım, brüt sabit sermaye oluşumu, reel döviz kuru ve ticarete açıklı̆ğn ekonomik büyüme üzerindeki etkilerini panel ARDL yöntemiyle araştırmaktadır. Panel ARDL'yi tahmin etmeden önce, ülkeler arasinda yatay kesit bağımlılı̆̆ının varlığını test edilmiştir. İkinci nesil panel birim kök testleri kullanarak değisskenlerin

\footnotetext{
* Anadolu University, Faculty of Economics and Administrative Sciences, Department of Economics, Eskişehir/ Turkey. Email: satlama@anadolu.edu.tr

* Anadolu University, Faculty of Economics and Administrative Sciences, Department of Economics, Eskişehir/ Türkiye. Email: muozer@anadolu.edu.tr
}

\section{Makale Gecmisii/Article History}


Yönetim ve Ekonomi Araștırmalar Dergisi / Journal of Management and Economics Research

Cilt/Volume: 19 Sayl/Issue: 3 Eylül/September 2021 ss. /pp. 94-114

S. Küçüksakarya, M. Özer http://dx.doi.org/10.11611/yead.972141

entegrasyon derecesi belirlenmiş ve aralarındaki eşbütünleşme incelenmiştir. Son olarak değişkenler arasındaki nedensel iliş̧kinin yönünü belirlemek için Dumitreuscu Hurlin nedensellik testi yapılmıştır. Çalışma sonuçlarl, ekonomik büyüme ile DYY, brüt sermaye oluşumu ve reel döviz kuru arasında uzun dönemli pozitif bir ilişkiye ve ticari açıklık ile uzun dönemli negatif bir ilişkiye işaret etmektedir. Çalışmanın bulguları, bu ülkelerin gelişmiş ülkelere ulaşmak için benimsemeleri gereken sanayi politikaları üzerinde önemli etkilere sahiptir.

Keywords: Ekonomik Büyüme, Yeni Sanayileşen Ülkeler, Panel ARDL, Panel Birim Kök Testleri, Panel Eşbütünleşme Testleri, Dumitrescu Hurlin Nedensellik Testi.

JEL Kodlart: C23, F43, O47, O49

\section{INTRODUCTION}

Today's highly competitive world to have a sustainable and inclusive growth, the countries should establish an economy heavily dependent on technology, advanced industry, and very efficient agriculture. To create such an environment, the countries should have enough human, capital, and/or natural resources.

Unfortunately, most of the countries has fallen shortages of enough capital resources and necessary technology to become a competitive country across the globe. Therefore, sum of the countries must attract foreign direct investment (FDI) and/or obtain foreign funds to finance their investments. Also, the countries should use their external competitiveness to increase their exports. Besides these, the countries ought to have highly skilled labor force. Thus, the countries that invest in more in capital resources, attracting more FDI in greenfield investment type, adopting export-led industrialization policies and finally enhancing the external competitiveness will have a sustainable growth.

Our data includes heterogeneities newly industrialized countries. These countries have some similarities but significant differences as well most of them has been trying to increase the share in the global value chain offering many opportunities for FDI and adopting highly competitive industrial policies. Sample countries differ from each other in terms of the GDP per capita, income inequality, human development index and their export and import share of world export and import. For example, according to the IMF in 2020 China has the largest GDP per capita with 10,839 USD, followed by Malaysia with 10,192 USD and India has the lowest GDP per capita with 1877 USD. South Africa has the worst income distribution, followed by Brazil and China. Thailand seems to have better income distribution relative to other countries in the sample based on the GINI coefficients for 2018. China has the largest share of World trade among the newly industrialized countries (NICs). According to World Trade Statistical Review 2020, China's share of global exports is $13.2 \%$ while it's share of imports is $10.8 \%$. Mexico follows China with $2.4 \%$ of both global exports and imports. Rest of the NIC countries 
shares vary between $2.5 \%$ (India's import share) to $0.4 \%$ (Philippines's export share). Based on the Human Development Index statistics for 2019, Malaysia and Turkey are ranked as very high; South Africa, Mexico, Brazil, China, Indonesia, Philippines, and Thailand are classified has high; while India is classified as a medium developed country.

The aim of this study to analyze these factors' effects on growth rate of NICs such as South Africa, Mexico, Brazil, China, India Indonesia, Malaysia Philippines, Thailand, and Turkey. For this purpose, we use panel data which consists of annual observations over the period of 1982 to 2019. We employ panel ARDL method to obtain the short and the long run relationships between GDP growth rate and foreign direct investment (FDI) to GDP ratio, gross fixed capital formation (GFCF) to GDP ratio, real exchange rate (REER) and trade openness (TO) GDP ratio.

Our study contributes the existing literature in two folds. First, to the best of our knowledge this is the first study examining the relationships among these variables for the NICs. Second, this is the first study to use external competitiveness in addition to traditional determinants of capital, foreign direct investment and trade openness.

According to the results of the cross-sectional dependence tests, there is a cross sectional dependence among the countries in the sample both across each variable and for the model. Also, both first and the second generation cointegration tests results indicate that there is a long run relationship between GDP growth rate and FDI, GFCF, REER and trade openness (TO). This result is confirmed by panel ARDL results as well indicating that all variables do have a statistically significant effects on economic growth in the long run. Finally, Dumitrescu-Hurlin panel causality test results provide evidence about the direction of the causality between the pairs of variables. Based on the results of the study, we can conclude that the countries having a high FDI to GDP ratio, high ratio of GFCF to GDP and high trade openness to GDP ratio along with enhancing the external competitiveness could have a high and sustained economic growth.

Our paper is organized as follows. Section two reviews the existing literature. Section three explains the data and preliminary analysis. Section four explains estimation strategy used in the study. Section five presents and discusses the empirical results. Section six presents our conclusions.

\section{LITERATURE REVIEW}

The factors affecting economic growth have been researched extensively in the literature by analyzing the effects of macro-economic variables such as FDI, trade openness, inflation, exchange rate, capital formation, financial development. The extant studies mostly use some combinations of these variables and include different country groups and/or individual countries. The panel data econometric methods are widely used especially in recent studies. 
Makki and Somwaru (2004) analyzed the effects of FDI and trade on economic growth in developing countries. They emphasized a significant positive effect of FDI and trade on economic growth. Klasra (2011) searched the effects of FDI, trade openness on GDP growth throughout the period of 1975 and 2004 by using the autoregressive distributed lags (ARDL) model. The findings of their study showed a bi-directional causality between FDI and exports for Turkey, and trade openness and exports relationship for Pakistan. Also, results of the said study show the presence of a long-run equilibrium relationship between variables. Adhikary (2011) investigated the relation between GDP growth rates, trade openness, FDI, capital formation of Bangladesh from 1986-2008. The result indicates a long-run equilibrium between economic growth and the variables. Pradhan, Bagchi, Chowdhury, and Norman (2012) found that there is long-run equilibrium between FDI, trade openness, and GDP growth using the panel VAR method for 10 OECD countries. Bibi, Ahmad, and Rahid (2014) examined the contribution of trade openness, inflation, exports, imports, exchange rate, and FDI to Pakistan's GDP growth for the period 1980-2011 using the Co-integration and DOLS techniques. They found that there is a long-run relationship between the selected variables. Asghar and Hussain (2014) analyzed the causal relationship between financial development, trade openness, and GDP growth in developing countries for 1978-2012. As a result of their studies, they found the existence of a long-run relationship between the variables. They also emphasized that there is a bidirectional causality between financial development and FDI. Yusoff and Febrina (2014) investigated the link between economic growth, domestic investment, real exchange rate, and trade openness in Indonesia by applying the Johansen cointegration test and Granger causality test. In their findings, they emphasized that there is a long-run relationship between the variables. Yusoff and Nuh (2015) emphasized FDI and trade openness are major determinants of GDP growth for Thailand.

Pradhan, Arvin, Hall, and Nair (2017) investigated the effects of selected macro-economic variables (trade openness, FDI, financial development) on economic growth by using a panel vector error correction model (VECM) for the period of 1988 to 2013 in 19 Eurozone countries. They found that the variables were cointegrated. Olabisi and Lau (2018) searched the link between trade openness, FDI, and economic growth using recently developed panel time series econometric methods in 23 SubSaharan African countries for 1980-2016. According to the findings of the study, there is a long-term cointegration between trade openness, FDI, and economic growth, and there is a positive and strong relation between economic growth, FDI and trade openness. Haque and Amin (2018) searched the relationship between trade openness, FDI, inflation, and economic growth in Bangladesh during the period of 1980 to 2015, using Granger Causality tests. According to their study's findings, while there is unidirectional causality from trade openness to economic growth, from trade openness to inflation, there is a bidirectional causal relationship between FDI and economic growth, unless, according to the study's findings, there is no causality between trade openness and inflation of FDI. Using a vector 
autoregressive model, Nguyen (2019) analyzed the relationship between trade openness, GDP growth, real exchange rate, and tariff rate for 3 Northeast Asian countries for 1998-2017. He found a long-term relationship between the selected variables. Nketiah, Cai, Adjei, and Boamah (2019) searched the effects of FDI, trade openness on GDP growth for Ghana throughout 1975 and 2017 using different techniques and found that the main factor affecting economic growth is trade openness in Ghana. Wiredu, Nketiah, and Adjei (2020) created a panel for four West African countries covering the years 1998-2017 and investigated the link between economic growth, FDI, and trade openness, and found a positive and significant relation between the variables.

Although majority of the studies existing in the empirical literature does include FDI and trade openness, there are some studies that also including the real exchange rate as an additional variable. However, there is no study considering the effects of FDI, trade openness, gross capital formation, and real exchange rate on economic growth. Moreover, it is hard to find any single study carried out for NICs. Therefore, it is extremely important to examine the effects of these variables on economic growth of NICs as a group, and this study is aims to this.

\section{DATA AND PRELIMINARY ANALYSIS}

This study uses panel data which consists of annual observations over the period of 1982 to 2019 to estimate the relationships between GDP growth rate and FDI to GDP ratio, gross fixed capital formation to GDP ratio, real exchange rate and trade openness to GDP ratio. The countries included in the sample are newly industrialized countries (NICs) ${ }^{1}$. These countries are South Africa, Brazil, Mexico, China, India, Indonesia, Malaysia, Philippines, Thailand and Turkey.

In the study, we use percentage real GDP growth rate as a dependent variable in panel ARDL estimates. As independent variables, we use ratio of FDI to GDP, ratio of gross fixed capital formation to GDP, real exchange rate and trade openness GDP ratio. We couldn't include any variable representing the labor input, since we failed to obtain any completed data about labor in sample countries. We use the real exchange rate as a proxy for external competitiveness of the countries. To measure the trade openness of the countries, we divide the sum of the exports and the imports by GDP. Table 1 provides a brief information about the variables and data sources and Table 2 represents the summary statistics of the variables. All the variables in the sample do have a positive mean during the study period. They all have an excess Kurtosis and do not have a normal distribution. GFCFGDP ratio exhibits highest volatility. Table 3 gives the estimated values of the pairwise correlations and their significance.

Table 1. List of Variables and Data Sources

\footnotetext{
${ }^{1}$ Newly industrialized countries are countries whose development level considered between developing and highly developed countries. 


\begin{tabular}{lll}
\hline Variable & Abbreviation & Data Source \\
\hline GDP Growth Rate (\%) & GDPGROWTH & World Development Indicators \\
\hline Ratio of Foreign Direct Investment to GDP (\%) & FDIGDP & World Development Indicators \\
\hline Ratio of Gross Fixed Capital Formation to GDP $(\boldsymbol{\%})$ & GFCFGDP & World Development Indicators \\
\hline Real Exchange Rate & REER & World Development Indicators \\
\hline Trade Openness GDP Ratio $(\%)$ & TO & World Development Indicators \\
\hline
\end{tabular}

Table 2. Summary Statistics

\begin{tabular}{|l|c|c|c|c|c|}
\hline & GDPGROWTH & FDIGDP & GFCFGDP & REER & TO \\
\hline Mean & 4.6671 & 1.8924 & 2.5071 & 1.0226 & 6.1888 \\
\hline Median & 4.9889 & 1.6411 & 2.3498 & 9.9371 & 5.0193 \\
\hline Maximum & 1.5192 & 8.7605 & 4.4519 & 2.5891 & 2.2041 \\
\hline Minimum & -1.3127 & -2.7574 & 1.4396 & 5.1167 & 1.2220 \\
\hline Std. Dev. & 3.8300 & 1.5760 & 6.8270 & 2.7567 & 4.2616 \\
\hline Skewness & -0.6400 & 0.8679 & 0.9572 & 1.8479 & 1.6696 \\
\hline Kurtosis & 4.7888 & 4.2995 & 3.4403 & 9.0938 & 5.5642 \\
\hline Jarque-Bera & 7.6600 & 7.4440 & 6.1098 & 8.0421 & 2.8065 \\
\hline Probability & 0.0000 & 0.0000 & 0.0000 & 0.0000 & 0.0000 \\
\hline Observations & 380 & 380 & 380 & 380 & 380 \\
\hline
\end{tabular}

Table 3. Pairwise Correlations

\begin{tabular}{|l|l|l|l|l|l|}
\hline Probability & GDPGROWTH & FDIGDP & GFCFGDP & REER & TO \\
\hline GDPGROWTH & 1.00 & & & & \\
\hline FDIGDP & $0.2101(0.0000)$ & 1.00 & & & \\
\hline GFCFGDP & $0.5173(0.0000)$ & $0.3077(0.0000)$ & 1.00 & & \\
\hline REER & $0.14471(0.0047)$ & $-0.0951(0.0641)$ & $0.2444(0.0000)$ & 1.00 & \\
\hline TO & $0.0373(0.4682)$ & $0.4529(0.0000)$ & $0.1537(0.0027)$ & $0.0292(0.5700)$ & 1.00 \\
\hline
\end{tabular}

Except for REER and FDIGDP, there is a positive correlation between the variables. But the correlations between TO and GDPGROWTH, and between TO and REER are not statistically significant. Figures 1-4 display scatter diagram between GDPGROWTH and each independent variable separately. 
Figure 1. The Real Exchange Rate and GDP Growth Rate (\%)

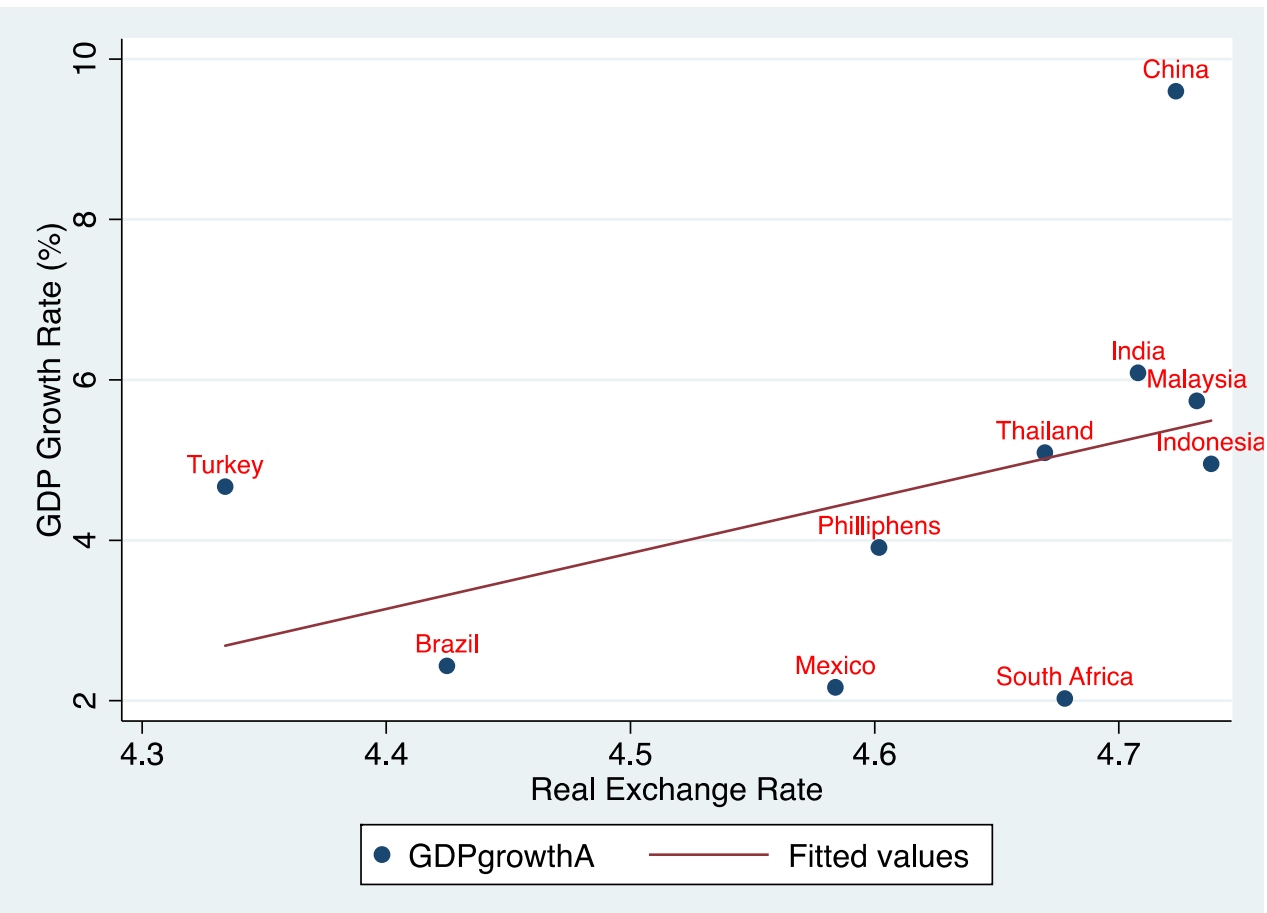

Figure 2. The Ratio of Foreign Direct Investment to GDP (\%) and GDP Growth Rate (\%)

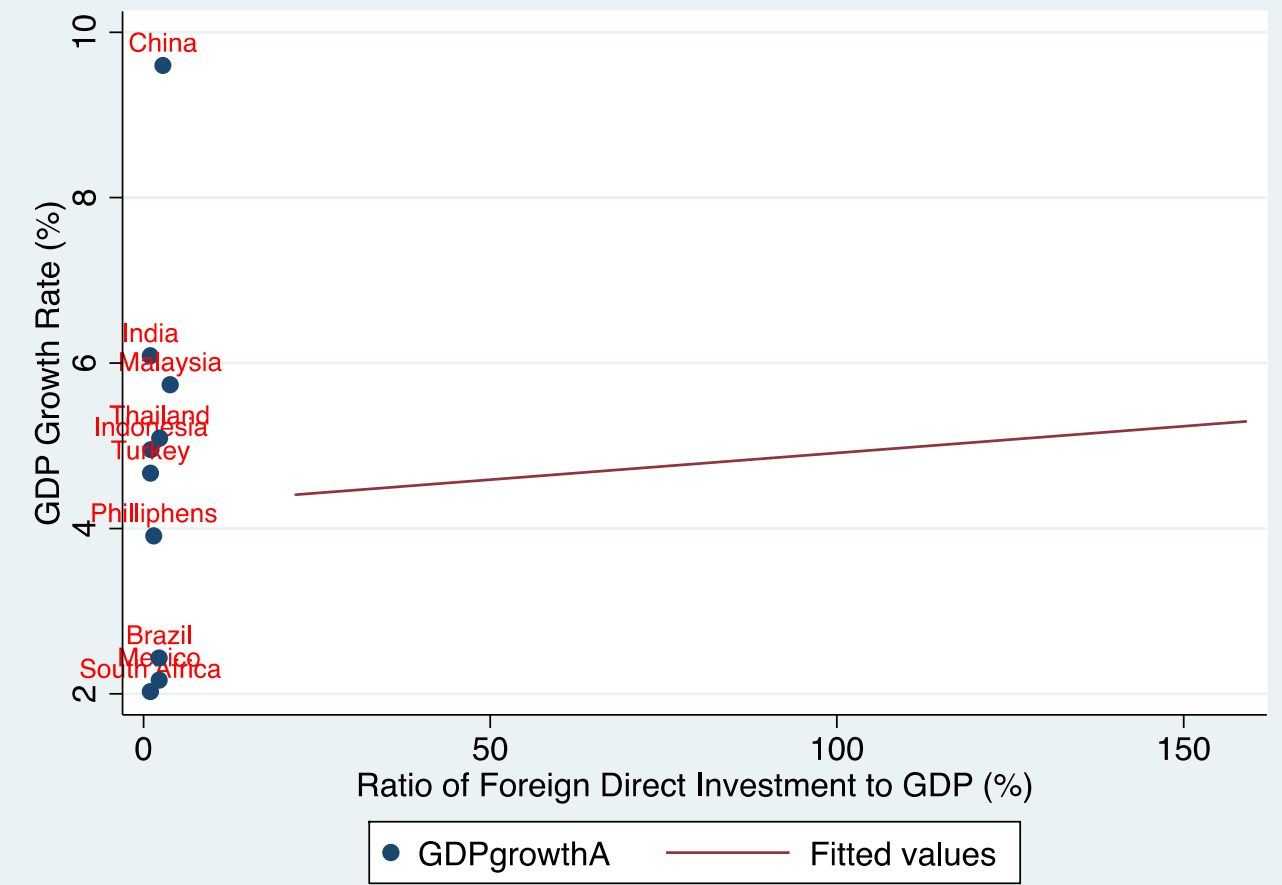


Figure 3. The Ratio of Gross Fixed Capital Formation to GDP (\%) and GDP Growth Rate (\%)

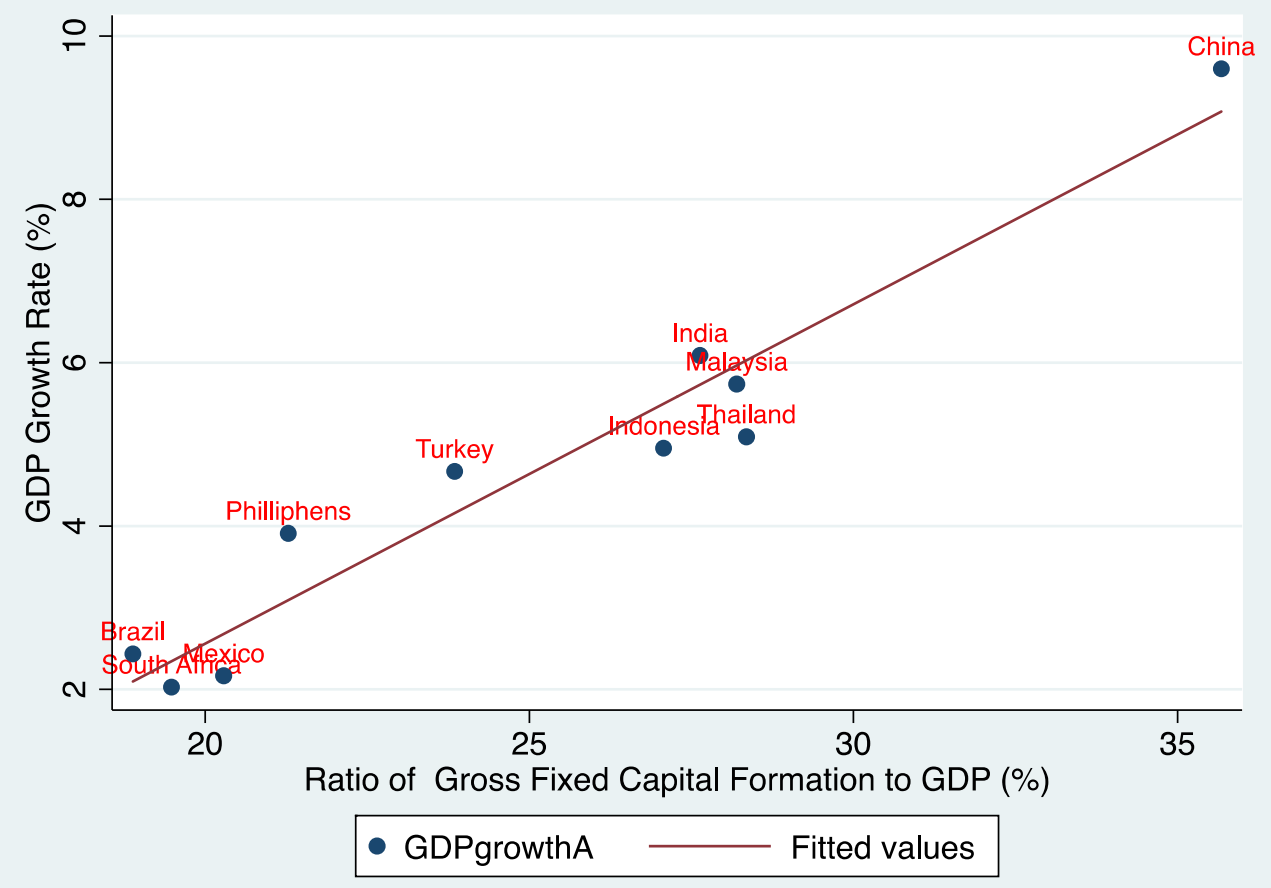

Figure 4. The Ratio of Trade Openness to GDP (\%) and GDP Growth Rate (\%)

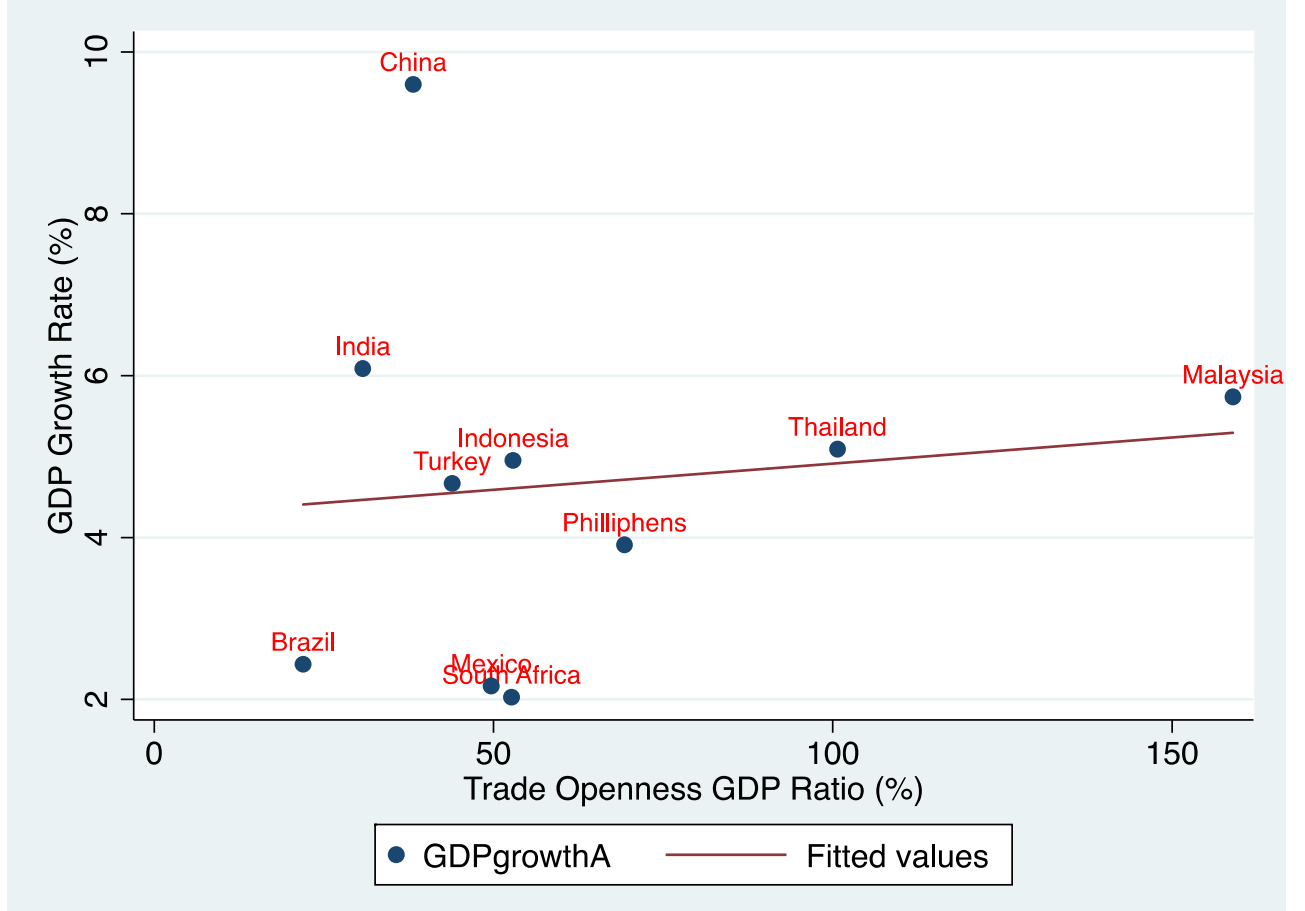

On average, except for the scatter diagram between GDPGROWTH and FDIGDP ratio which displays no definite relation, all scatter diagrams show a positive relationship between GDPGROWTH and each independent variable. China seems to be an outlier in each case showing high average growth 
rate during the period. The scatter diagram between GDPGROWTH and GFCFGDP ratio shows positive relationship between two variables.

\section{ESTIMATION STRATEGY}

To estimate the relationship between GDP growth rate and FDI to GDP ratio, GFCF to GDP ratio, REER and trade openness GDP ratio, we start by testing the presence of cross-sectional dependence among the countries to implement appropriate panel unit root and cointegration tests. For this purpose, we carry out cross sectional dependence tests such as Lagrange Multiplier-LM test of Breusch-Pagan (1980)'s and the Cross-section Dependence-CD test of Pesaran (2004)'s and BiasAdjusted Cross Sectionally Dependence Lagrange Multiplier- $\mathrm{CD}_{\mathrm{LM}}$ test of Pesaran, Ullah and Yamagata (2008)'s for each variable and the model.

After finding the presence of cross-sectional dependence, we examine the unit root properties of the variables using two of the most popular the second-generation panel unit root tests. The first one is the cross-section augmented Dickey-Fuller (CADF) developed by Im , Pesaran and Shin (2003), and the second is the cross-sectionally augmented IPS (CIPS) tests developed by Pesaran (2007). Also, to determine the presence of long-run relationship among the variables, we carry out both first generation and second generation cointegration tests to cross validate the results. For this purpose, we use two first generation cointegration tests of KAO and Pedroni which are based on Engle-Granger (1987) two-step (residual-based) cointegration tests and second-generation cointegration test of Westerlund errorcorrection-based panel cointegration tests developed by Westerlund (2007).

After establishing the degrees of integration of the variables, which are not I(2) and finding evidence of cointegration among the variables, we continue our analysis estimating the panel ARDL model to obtain the short and the long run effects of variables on economic growth. One of the methods used to determine whether there is cointegration between variables in panel data is the Panel ARDL approach. With this approach, it is investigated whether there is cointegration among the variables in a panel with different degrees of integration. The estimator used to estimate the panel ARDL is the pooled mean group (PMG) estimator developed by Pesaran and Smith (1997). This estimator is a preferred estimator for estimating dynamic panels with large number of sections and time. It allows us to estimate different constant term, different error variance and short-term effects for each cross-section unit in the panel by means of the PMG estimator. In the study, this situation will be valid for every country. In contrast, the long-run coefficients remain the same for all countries. We can also estimate the estimated value of the coefficient of fit using the PMG method. Speed of adjustment coefficients is the estimated value of the coefficient of error correction term in the model showing short-term effects. With this coefficient, we have the opportunity to determine the degree of compliance in each period. In other 
words, we determine the time required to reach a new equilibrium as a result of an imbalance with the help of this coefficient.

To form the panel ARDL model, we start with following economic growth model:

\section{GDPGROWTH=f(FDIGDP,GFCFGDP,REER,TO)}

The ARDL(p,q,q,..,q) model, which we estimated to investigate the link between dependent and independent variables, is as follows:

$Y_{i t}=\sum_{j=1}^{p} \alpha_{i j} Y_{i, t-j}+\sum_{j=0}^{q} \delta_{i j}^{\prime} X_{i, t-j}+\mu_{i}+\varepsilon_{i t}$

Where $X_{\mathrm{it}}=(\mathrm{FDIGDP}, \mathrm{GFCFGDP}, \mathrm{REER}, \mathrm{TO})$. By rearranging the Equation (2), we obtain the Panel error correction model.

$\Delta Y_{i t}=\phi_{i}\left(Y_{i, t-1}-\beta_{i}^{\prime} X_{i, t-1}\right)+\sum_{j=1}^{p-1} \alpha_{i j}^{*} \Delta Y_{i, t-j}+\sum_{j=0}^{q-1} \delta_{i j}^{* \prime} \Delta X_{i, t-j}+\mu_{i}+\varepsilon_{i t}$

The coefficient vector $\beta_{i}$ in equation (2) gives the long-term coefficients, which are the main coefficients we tried to estimate in the study. In other words, it represents the long-term effects of FDI to GDP ratio, gross fixed capital formation to GDP ratio, real exchange rate and trade openness GDP ratio on real GDP growth rate. $\phi$ gives speed of adjustment coefficient and the remaining coefficients give the short-term effects. The $\varepsilon_{i t}$ means the error term with zero and constant variance and a distribution independent of both time and cross-section units.

Finally, we use Dumitrescu-Hurlin panel granger causality test to determine the directions of the causality between the pairs of variables.

\section{EMPIRICAL RESULTS}

We start our empirical analysis by testing the existence of cross-sectional dependence for each variable and the model carrying out cross-sectional dependence tests of Lagrange Multiplier-LM test of Breusch-Pagan (1980) and Cross-section Dependence-CD test developed by Pesaran (2004) and BiasAdjusted Cross Sectionally Dependence Lagrange Multiplier- $\mathrm{CD}_{\mathrm{LM}}$ test improved by Pesaran et al. (2008) and Table 4 presents these results. 
Yönetim ve Ekonomi Araștırmalarl Dergisi / Journal of Management and Economics Research

Cilt/Volume: 19 Sayl/Issue: 3 Eylül/September 2021 ss./pp. 94-114

S. Küçüksakarya, M. Özer http://dx.doi.org/10.11611/yead.972141

Table 4. The Results of the Cross-Sectional Dependence Tests

\begin{tabular}{|l|c|c|c|l|l|c|}
\hline Test & GDPGROWTH & FDIGDP & GFCFGDP & REER & TO & MODEL $^{*}$ \\
\hline CD $_{\text {BP }}$ & 129.0496 & 228.6496 & 270.7195 & 438.1262 & 577.0710 & 154.7466 \\
& $(0.0000)$ & $(0.0000)$ & $(0.0000)$ & $(0.0000)$ & $(0.0000)$ & $(0.0000)$ \\
\hline CDLM & 8.859609 & 19.35836 & 23.79292 & 41.43914 & 56.08521 & 11.56831 \\
& $(0.0000)$ & $(0.0000)$ & $(0.0000)$ & $(0.0000)$ & $(0.0000)$ & $(0.0000)$ \\
\hline CD & 6.850744 & 10.14302 & 2.915032 & 10.67677 & 19.40778 & 7.547271 \\
& $(0.0000)$ & $(0.0000)$ & $(0.0000)$ & $(0.0000)$ & $(0.0000)$ & $(0.0000)$ \\
\hline LM $_{\text {adj }}$ & 8.724474 & 19.22323 & 23.65779 & 41.30401 & 55.95007 & 11.43317 \\
& $(0.0000)$ & $(0.0000)$ & $(0.0000)$ & $(0.0000)$ & $(0.0000)$ & $(0.0000)$ \\
\hline${ }^{*}$ GDPGROWTH=f(FDIGDP,GFCFGDP,REER,TO) \\
\hline
\end{tabular}

The cross-sectional dependence tests result in Table 4 show that there is a cross sectional dependence across both variables and the models. Therefore, we continue our empirical analysis by implementing second generation panel unit root tests of CADF and CIPS to determine the degree of the integration of variables and Table 5 displays results of these tests.

Table 5. The Results of Panel Unit Root Tests

\begin{tabular}{|c|c|c|c|}
\hline Variables & CADF & CIPS $^{+}$ & Result \\
\hline GDPGROWTH & $-4.342 *(0.0000)$ & -3.851 & \multirow[t]{2}{*}{$\mathrm{I}(1)$} \\
\hline DGDPGROWTH & $-11.339 *(0.0000)$ & -6.001 & \\
\hline FDIGDP & $-3.254 *(0.001)$ & -3.125 & \multirow[t]{2}{*}{$\mathrm{I}(1)$} \\
\hline DFDIGDP & $-10.599 *(0.0000)$ & -5.870 & \\
\hline GFCFGDP & $-0.898(0.185)$ & -1.813 & \multirow[t]{2}{*}{$\mathrm{I}(1)$} \\
\hline DGFCFGDP & $-8.432 *(0.000)$ & -5.178 & \\
\hline REER & $-1.126(0.130)$ & -2.164 & \multirow[t]{2}{*}{$\mathrm{I}(1)$} \\
\hline DREER & $-8.624 *(0.000)$ & -5.426 & \\
\hline TO & $0.849(0.802)$ & -1.235 & \multirow[t]{2}{*}{$\mathrm{I}(1)$} \\
\hline DTO & $-6.709 *(0.000)$ & -4.610 & \\
\hline $\begin{array}{l}\text { Notes: } \\
\text { i. Numbers in pare } \\
\text { ii.* indicates the si } \\
\text { iii. }{ }^{+} \text {table critical v }\end{array}$ & $\begin{array}{l}\text { p-values of the test statistics. } \\
\text { of the test statistic at } 1 \text { percent } \\
2.21,-2.33,-2.55 \text { at } 1,5 \text { and } 10\end{array}$ & $\begin{array}{l}\text { gnificance levels. } \\
\text { ercent significance }\end{array}$ & els. \\
\hline
\end{tabular}

The results of panel unit root tests tell us that we can search the existence of long run relationship among the variables and obtain the short and the long run effects of independent variables on economic growth by using panel ARDL since none of the variable is $\mathrm{I}(2)$. Table 6 includes the results of cointegration tests. 
Table 6. The Results of Cointegration Tests

\begin{tabular}{|c|c|c|c|c|c|c|}
\hline First Generation C & ointegratio & ests & Second & eration $\mathrm{C}$ & ntegratio & est \\
\hline Model: GDPGROY & $\mathrm{TH}=\mathrm{f}(\mathrm{FDIC}$ & ,GFCFGD & REER,TC & & & \\
\hline Pedroni Residual & ointegratio & est & Westerl & Test & & \\
\hline & Statistic & $\mathrm{p}$-value & Statistic & Value & Z-value & P-value \\
\hline Panel v-Statistic & -0.484910 & 0.6861 & Gt & -3.942 & -6.038 & $0.000^{*}$ \\
\hline Panel rho-Statistic & -2.713461 & $0.0033 *$ & $\mathrm{Ga}$ & -16.053 & -2.745 & $0.003 *$ \\
\hline Panel PP-Statistic & -6.775855 & $0.0000^{*}$ & $\mathrm{Pt}$ & -11.465 & -5.014 & $0.000 *$ \\
\hline $\begin{array}{l}\text { Panel ADF- } \\
\text { Statistic }\end{array}$ & -4.942956 & $0.0000 *$ & $\mathrm{~Pa}$ & -20.105 & -6.052 & $0.000 *$ \\
\hline & Statistic & p-value & Notor & ostarlun & f & \\
\hline $\begin{array}{l}\text { Group rho- } \\
\text { Statistic }\end{array}$ & -1.209990 & 0.1131 & $\begin{array}{l}\text { cointegr: } \\
\text { regressic }\end{array}$ & $\begin{array}{l}a \text { as the } n \\
\text { with a ce }\end{array}$ & $\begin{array}{l}\text { hypothesi } \\
\text { ant, and a }\end{array}$ & \\
\hline Group PP-Statistic & -9.757459 & $0.0000 *$ & lags $(1,1$ & nd leads ( & & \\
\hline $\begin{array}{l}\text { Group ADF- } \\
\text { Statistic }\end{array}$ & -5.666913 & $0.0000 *$ & & & & \\
\hline Kao Residual Coin & tegration $\mathbf{T}$ & & & & & \\
\hline ADF t-Stat & -7.269756 & $0.0000 *$ & & & & \\
\hline $\begin{array}{l}*, * * * * * \text { represent } \\
\text { significance. }\end{array}$ & $\%, 5 \%$ and & level of & & & & \\
\hline
\end{tabular}

Fortunately, results of the both first and second generation cointegration tests show that there is a long-run relationship among variables so we can use both panel ARDL and Dumitruescu Hurlin test to determine the causality among variables, since the existence of cointegration implies the causality between variables. Table 7 presents short and long run PMG estimates of our model. 
Yönetim ve Ekonomi Araștırmalar Dergisi / Journal of Management and Economics Research

Cilt/Volume: 19 Sayı/Issue: 3 Eylül/September 2021 ss./pp. 94-114

S. Küçüksakarya, M. Özer http://dx.doi.org/10.11611/yead.972141

Table 7. Panel ARDL Short and Long Run Equation Results (PMG)

\begin{tabular}{|c|c|c|c|c|}
\hline \multicolumn{5}{|c|}{ Dependent Variable= GDPGROWTH } \\
\hline Variable & Coefficient & Std. Error & t-Statistic & Prob. \\
\hline \multicolumn{5}{|l|}{ Long- Run Equation } \\
\hline FDIGDP & 0.892929 & 0.096804 & 9.224051 & $0.0000 *$ \\
\hline GFCFGDP & 0.058021 & 0.031916 & 1.817917 & $0.0717 * * *$ \\
\hline REER & 0.050297 & 0.010702 & 4.699768 & $0.0000 *$ \\
\hline TO & -0.056317 & 0.007616 & -7.395021 & $0.0000 *$ \\
\hline \multicolumn{5}{|l|}{ Short- Run Equation } \\
\hline ECT & -0.804930 & 0.246237 & -3.268930 & $0.0014 *$ \\
\hline D(GDPGROWTH(-1)) & -0.050528 & 0.223337 & -0.226241 & 0.8214 \\
\hline D(GDPGROWTH(-2)) & -0.154652 & 0.193928 & -0.797469 & 0.4268 \\
\hline D(GDPGROWTH(-3)) & -0.084755 & 0.126299 & -0.671062 & 0.5035 \\
\hline D(GDPGROWTH(-4)) & -0.017497 & 0.076810 & -0.227797 & 0.8202 \\
\hline $\mathrm{D}($ FDIGDP) & -0.477030 & 0.421299 & -1.132284 & 0.2599 \\
\hline D(FDIGDP(-1)) & -0.713664 & 0.508023 & -1.404787 & 0.1628 \\
\hline D(FDIGDP(-2)) & -0.563907 & 0.488014 & -1.155514 & 0.2503 \\
\hline D(FDIGDP(-3)) & -0.969335 & 0.338651 & -2.862337 & $0.0050 *$ \\
\hline D(FDIGDP(-4)) & -1.115455 & 0.529520 & -2.106539 & $0.0373 * *$ \\
\hline $\mathrm{D}$ (GFCFGDP) & 0.483301 & 0.152321 & 3.172915 & $0.0019 *$ \\
\hline $\mathrm{D}($ GFCFGDP(-1)) & -0.038731 & 0.125866 & -0.307717 & 0.7588 \\
\hline $\mathrm{D}(\operatorname{GFCFGDP}(-2))$ & 0.007619 & 0.248568 & 0.030651 & 0.9756 \\
\hline $\mathrm{D}(\operatorname{GFCFGDP}(-3))$ & -0.345014 & 0.193476 & -1.783242 & $0.0772 * * *$ \\
\hline $\mathrm{D}(\mathrm{GFCFGDP}(-4))$ & -0.024905 & 0.192796 & -0.129179 & 0.8974 \\
\hline D(REER) & 0.112574 & 0.039382 & 2.858501 & $0.0050 *$ \\
\hline $\mathrm{D}(\operatorname{REER}(-1))$ & 0.051128 & 0.034016 & 1.503064 & 0.1355 \\
\hline $\mathrm{D}(\operatorname{REER}(-2))$ & 0.001415 & 0.039127 & 0.036167 & 0.9712 \\
\hline $\mathrm{D}(\operatorname{REER}(-3))$ & -0.023976 & 0.051108 & -0.469129 & 0.6399 \\
\hline $\mathrm{D}(\operatorname{REER}(-4))$ & -0.047264 & 0.044069 & -1.072512 & 0.2857 \\
\hline $\mathrm{D}(\mathrm{TO})$ & 0.206587 & 0.129297 & 1.597778 & 0.1128 \\
\hline $\mathrm{D}(\mathrm{TO}(-1))$ & 0.156896 & 0.096999 & 1.617498 & 0.1085 \\
\hline $\mathrm{D}(\mathrm{TO}(-2))$ & 0.116624 & 0.064069 & 1.820282 & $0.0713 * * *$ \\
\hline $\mathrm{D}(\mathrm{TO}(-3))$ & 0.165384 & 0.135417 & 1.221287 & 0.2245 \\
\hline $\mathrm{D}(\mathrm{TO}(-4))$ & 0.065081 & 0.094616 & 0.687839 & 0.4929 \\
\hline $\mathrm{C}$ & 0.323743 & 0.909654 & 0.355896 & 0.7226 \\
\hline \multicolumn{5}{|l|}{ Notes: } \\
\hline \multicolumn{5}{|c|}{$\begin{array}{l}*, * * \text { and } * * * \text { indicates } 1 \%, 5 \% \text { and } 10 \% \text { significance level respectively. } \\
\text { ECT stands for error correction term. }\end{array}$} \\
\hline
\end{tabular}

Except for TO, the long-run estimates of the coefficients indicate that there is a positive and significant relationship between economic growth and each independent variable. Also, there is a negative relation between TO and GDPGROWTH. The reason for this is that most of the countries in the sample suffered from the trade deficit in most of the sample period. Even China started to have trade surplus only after 2003.

When we examine the short-run estimates, we can easily conclude that there are significant and insignificant lag values of the independent variables. Speed of adjustment coefficient is negative and less than one and statistically significant. It implies that approximately $80 \%$ of the imbalances are 
Yönetim ve Ekonomi Araștırmaları Dergisi / Journal of Management and Economics Research

Cilt/Volume: 19 Sayl/Issue: 3 Eylül/September 2021 ss. /pp. 94-114

S. Küçüksakarya, M. Özer http://dx.doi.org/10.11611/yead.972141

corrected within a year. It takes more than a year to restore the equilibrium. Table 8 summarizes the country specific short run results. 
S. Küçüksakarya, M. Özer http://dx.doi.org/10.11611/yead.972141

Table 8. Country Specific Short Run Dynamics

\begin{tabular}{|c|c|c|c|c|c|c|c|c|c|c|}
\hline Variable & South Africa & Mexico & Brazil & China & India & Indonesia & Malaysia & Philliphens & Thailand & Turkey \\
\hline ECT & $\begin{array}{r}-0,5311^{*} \\
0.0002 \\
\end{array}$ & $\begin{array}{r}-0,0338 \\
0.4185 \\
\end{array}$ & $\begin{array}{r}-1,2407 * \\
0.0004 \\
\end{array}$ & $\begin{array}{r}-0,3743^{*} \\
0.0000 \\
\end{array}$ & $\begin{array}{r}1,3742^{*} \\
0.0027 \\
\end{array}$ & $\begin{array}{l}0,2067 \\
0.0431 \\
\end{array}$ & $\begin{array}{r}-0,8206^{*} \\
0.0000 \\
\end{array}$ & $\begin{array}{r}-0,0700^{*} \\
0.0038 \\
\end{array}$ & $\begin{array}{r}-2,1304 * \\
0.0007 \\
\end{array}$ & $\begin{array}{r}-1,6809^{*} \\
0.0003 \\
\end{array}$ \\
\hline D(GDPGROWTH(-1)) & $\begin{array}{r}0,1639 * * \\
0.0209\end{array}$ & $\begin{array}{r}-1,5658 * \\
0.0001\end{array}$ & $\begin{array}{r}0,2758 * \\
0.0036\end{array}$ & $\begin{array}{r}-0,0068 \\
0.5020\end{array}$ & $\begin{array}{r}0,4019 * * \\
0.0256\end{array}$ & $\begin{array}{r}-0,9501 * \\
0.0012\end{array}$ & $\begin{array}{r}0,4993^{*} \\
0.0007\end{array}$ & $\begin{array}{r}-0,2668^{*} \\
0.0003\end{array}$ & $\begin{array}{r}0,7270^{*} \\
0.0043\end{array}$ & $\begin{array}{r}0,2163 * * \\
0.0529\end{array}$ \\
\hline D(GDPGROWTH(-2)) & $\begin{array}{r}0,1951 * \\
0.0032\end{array}$ & $\begin{array}{r}-1,4348 * \\
0.0002\end{array}$ & $\begin{array}{r}0,0671 * * \\
0.0143\end{array}$ & $\begin{array}{r}-0,2455^{*} \\
0.0000\end{array}$ & $\begin{array}{l}0,1929 \\
0.0372\end{array}$ & $\begin{array}{r}-0,9687 * \\
0.0003\end{array}$ & $\begin{array}{r}0,6960 * \\
0.0003\end{array}$ & $\begin{array}{r}-0,0164 \\
0.3173\end{array}$ & $\begin{array}{l}0,0130 \\
0.8102\end{array}$ & $\begin{array}{r}-0,0451 \\
0.4803\end{array}$ \\
\hline D(GDPGROWTH(-3)) & $\begin{array}{r}-0,3552 * \\
0.0005\end{array}$ & $\begin{array}{r}-0,6300 * \\
0.0004\end{array}$ & $\begin{array}{l}0,0265 \\
0.2354\end{array}$ & $\begin{array}{r}-0,1613^{*} \\
0.0000\end{array}$ & $\begin{array}{l}0,0087 \\
0.9123\end{array}$ & $\begin{array}{r}-0,7055^{*} \\
0.0001\end{array}$ & $\begin{array}{r}0,5067 * \\
0.0002\end{array}$ & $\begin{array}{r}0,1843^{*} \\
0.0006\end{array}$ & $\begin{array}{r}-0,1162 \\
0.0201\end{array}$ & $\begin{array}{r}0,3945 * \\
0.0004\end{array}$ \\
\hline D(GDPGROWTH(-4)) & $\begin{array}{r}-0,1634^{*} \\
0.0018\end{array}$ & $\begin{array}{r}-0,0107 \\
0.1159\end{array}$ & $\begin{array}{r}0,3784^{*} \\
0.0000\end{array}$ & $\begin{array}{r}-0,1875 * \\
0.0001\end{array}$ & $\begin{array}{l}0,1894 \\
0.0185\end{array}$ & $\begin{array}{r}-0,4615^{*} \\
0.0010\end{array}$ & $\begin{array}{r}0,1606^{*} \\
0.0001\end{array}$ & $\begin{array}{r}-0,2124 * \\
0.0000\end{array}$ & $\begin{array}{l}0,0523 \\
0.0026\end{array}$ & $\begin{array}{r}0,0797 * \\
0.0007\end{array}$ \\
\hline D(FDIGDP) & $\begin{array}{r}-0,9288^{*} \\
0.0001 \\
\end{array}$ & $\begin{array}{r}-0,4515 * * * \\
0.0717 \\
\end{array}$ & $\begin{array}{r}-0,8945^{*} \\
0.0055\end{array}$ & $\begin{array}{r}0,8414 * \\
0.0001 \\
\end{array}$ & $\begin{array}{r}-2,7824 \\
0.0209 \\
\end{array}$ & $\begin{array}{l}1,7476 \\
0.0006\end{array}$ & $\begin{array}{r}0,8845^{*} \\
0.0002\end{array}$ & $\begin{array}{r}-1,1335^{*} \\
0.0005\end{array}$ & $\begin{array}{r}-1,6202 \\
0.0039 \\
\end{array}$ & $\begin{array}{r}-0,4328 \\
0.2389 \\
\end{array}$ \\
\hline D(FDIGDP(-1)) & $\begin{array}{r}-1,4253^{*} \\
0.0000 \\
\end{array}$ & $\begin{array}{r}-1,8463^{*} \\
0.0040 \\
\end{array}$ & $\begin{array}{r}-0,0861 \\
0.2507 \\
\end{array}$ & $\begin{array}{l}0,0942 \\
0.1377 \\
\end{array}$ & $\begin{array}{r}-3,9232 \\
0.0317 \\
\end{array}$ & $\begin{array}{l}1,5229 \\
0.0024 \\
\end{array}$ & $\begin{array}{r}-0,2219^{*} \\
0.0066 \\
\end{array}$ & $\begin{array}{r}-0,6000 * * \\
0.0111 \\
\end{array}$ & $\begin{array}{r}-1,8309 \\
0.0004 \\
\end{array}$ & $\begin{array}{r}1,1799 * * \\
0.0169 \\
\end{array}$ \\
\hline D(FDIGDP(-2)) & $\begin{array}{r}-1,1204^{*} \\
0.0000 \\
\end{array}$ & $\begin{array}{r}-4,2328^{*} \\
0.0018 \\
\end{array}$ & $\begin{array}{l}0,0259 \\
0.7173 \\
\end{array}$ & $\begin{array}{r}0,7793^{*} \\
0.0000 \\
\end{array}$ & $\begin{array}{l}0,7926 \\
0.6757 \\
\end{array}$ & $\begin{array}{l}0,2449 \\
0.0478 \\
\end{array}$ & $\begin{array}{l}0,3694 \\
0.0007 \\
\end{array}$ & $\begin{array}{l}0,1022 \\
0.3445 \\
\end{array}$ & $\begin{array}{r}-1,8565 \\
0.0002 \\
\end{array}$ & $\begin{array}{r}-0,7437 \\
0.0966 \\
\end{array}$ \\
\hline D(FDIGDP(-3)) & $\begin{array}{r}-0,9592^{*} \\
0.0000 \\
\end{array}$ & $\begin{array}{r}-3,3319 * * \\
0.0103 \\
\end{array}$ & $\begin{array}{r}0,4698 * * \\
0.0110 \\
\end{array}$ & $\begin{array}{r}-1,0417^{*} \\
0.0000 \\
\end{array}$ & $\begin{array}{r}-0,9250 \\
0.2731 \\
\end{array}$ & $\begin{array}{l}0,4365 \\
0.0080 \\
\end{array}$ & $\begin{array}{r}-0,4295 \\
0.0003 \\
\end{array}$ & $\begin{array}{r}-1,2323^{*} \\
0.0016 \\
\end{array}$ & $\begin{array}{r}-1,4974^{*} \\
0.0002 \\
\end{array}$ & $\begin{array}{r}-1,1825^{* *} \\
0.0183 \\
\end{array}$ \\
\hline D(FDIGDP(-4)) & $\begin{array}{r}-0,9185^{*} \\
0.0000 \\
\end{array}$ & $\begin{array}{r}-1,1754 * * \\
0.0244 \\
\end{array}$ & $\begin{array}{r}-1,7840^{*} \\
0.0007 \\
\end{array}$ & $\begin{array}{r}0,2424 * \\
0.0057 \\
\end{array}$ & $\begin{array}{r}-5,3025^{* *} \\
0.0127 \\
\end{array}$ & $\begin{array}{r}-0,1773 \\
0.1822 \\
\end{array}$ & $\begin{array}{r}0,5451 * \\
0.0007 \\
\end{array}$ & $\begin{array}{r}-1,8412^{*} \\
0.0001\end{array}$ & $\begin{array}{r}-0,5944^{*} \\
0.0014\end{array}$ & $\begin{array}{r}-0,1486 \\
0.7216\end{array}$ \\
\hline D(GFCFGDP) & $\begin{array}{r}-0,5882 * \\
0.0021 \\
\end{array}$ & $\begin{array}{r}0,9834^{*} \\
0.0002 \\
\end{array}$ & $\begin{array}{r}1,1247 * \\
0.0000 \\
\end{array}$ & $\begin{array}{r}0,1520^{*} \\
0.0000 \\
\end{array}$ & $\begin{array}{r}0,5471 * \\
0.0012 \\
\end{array}$ & $\begin{array}{r}0,3414^{*} \\
0.0047 \\
\end{array}$ & $\begin{array}{r}0,2903 * \\
0.0000 \\
\end{array}$ & $\begin{array}{r}0,5698 * \\
0.0001 \\
\end{array}$ & $\begin{array}{r}0,7198 * \\
0.0000 \\
\end{array}$ & $\begin{array}{r}0,6928 * \\
0.0001 \\
\end{array}$ \\
\hline $\mathrm{D}(\mathrm{GFCFGDP}(-1))$ & $\begin{array}{r}-0,4404^{*} \\
0.0063\end{array}$ & $\begin{array}{r}-0,0737 \\
0.3965\end{array}$ & $\begin{array}{l}0,1620 \\
0.1058\end{array}$ & $\begin{array}{r}0,2951 * \\
0.0000\end{array}$ & $\begin{array}{l}0,1511 \\
0.1729\end{array}$ & $\begin{array}{r}-0,4569 * \\
0.0026\end{array}$ & $\begin{array}{r}-0,7654^{*} \\
0.0000\end{array}$ & $\begin{array}{r}-0,0436 * * \\
0.0494\end{array}$ & $\begin{array}{r}0,4136^{*} \\
0.0004\end{array}$ & $\begin{array}{r}0,3710 * * \\
0.0118\end{array}$ \\
\hline $\mathrm{D}(\mathrm{GFCFGDP}(-2))$ & $\begin{array}{r}0,7212 * \\
0.0005\end{array}$ & $\begin{array}{r}-1,9828 * \\
0.0000\end{array}$ & $\begin{array}{r}0,6759 * \\
0.0002\end{array}$ & $\begin{array}{r}0,0829 * \\
0.0002\end{array}$ & $\begin{array}{r}-0,0947 \\
0.2324\end{array}$ & $\begin{array}{r}0,0702 * * * \\
0.0982\end{array}$ & $\begin{array}{r}-0,4048 * \\
0.0001\end{array}$ & $\begin{array}{r}0,2472 * \\
0.0015\end{array}$ & $\begin{array}{r}0,6228 * \\
0.0001\end{array}$ & $\begin{array}{r}0,1384 * * \\
0.0408\end{array}$ \\
\hline $\mathrm{D}(\mathrm{GFCFGDP}(-3))$ & $\begin{array}{r}-0,7618 * \\
0.0002\end{array}$ & $\begin{array}{r}-1,4684^{*} \\
0.0043\end{array}$ & $\begin{array}{r}-0,2516^{*} \\
0.0002\end{array}$ & $\begin{array}{r}0,2161 * \\
0.0000\end{array}$ & $\begin{array}{r}0,3450^{* *} \\
0.0323\end{array}$ & $\begin{array}{r}0,1180^{* *} \\
0.0167\end{array}$ & $\begin{array}{r}-0,0987 * \\
0.0005\end{array}$ & $\begin{array}{r}-0,7112 * \\
0.0001\end{array}$ & $\begin{array}{r}0,1786^{*} \\
0.0017\end{array}$ & $\begin{array}{r}-1,0160 * \\
0.0005\end{array}$ \\
\hline
\end{tabular}



Cilt/Volume: 19 Sayl/Issue: 3 Eylül/September 2021 ss./pp. 94-114

S. Küçüksakarya, M. Özer http://dx.doi.org/10.11611/yead.972141

\begin{tabular}{|c|c|c|c|c|c|c|c|c|c|c|}
\hline D(GFCFGDP(-4)) & $\begin{array}{r}0,1798 * * * \\
0.0673\end{array}$ & $\begin{array}{r}-1,5928 * \\
0.0002\end{array}$ & $\begin{array}{r}-0,1004^{* *} \\
0.0108\end{array}$ & $\begin{array}{r}0,3129 * \\
0.0000\end{array}$ & $\begin{array}{l}0,0043 \\
0.9736\end{array}$ & $\begin{array}{r}-0,1168^{* *} \\
0.0127\end{array}$ & $\begin{array}{r}-0,1619 * \\
0.0001\end{array}$ & $\begin{array}{r}0,7025^{*} \\
0.0001\end{array}$ & $\begin{array}{r}0,3057 * \\
0.0005\end{array}$ & $\begin{array}{r}0,2177 * * \\
0.0028\end{array}$ \\
\hline D(REER) & $\begin{array}{r}0,0650^{*} \\
0.0000\end{array}$ & $\begin{array}{r}0,3005^{*} \\
0.0000 \\
\end{array}$ & $\begin{array}{r}0,0732 * \\
0.0000\end{array}$ & $\begin{array}{r}-0,1034^{*} \\
0.0000\end{array}$ & $\begin{array}{r}0,2350 * \\
0.0001 \\
\end{array}$ & $\begin{array}{l}0,0024 \\
0.3193\end{array}$ & $\begin{array}{r}0,2642 * \\
0.0000\end{array}$ & $\begin{array}{r}0,0559 * \\
0.0000\end{array}$ & $\begin{array}{r}0,1017 * \\
0.0003 \\
\end{array}$ & $\begin{array}{r}0,1312 * \\
0.0001 \\
\end{array}$ \\
\hline $\mathrm{D}(\operatorname{REER}(-1))$ & $\begin{array}{r}0,0300 * \\
0.0000 \\
\end{array}$ & $\begin{array}{r}0,1857 * \\
0.0000 \\
\end{array}$ & $\begin{array}{r}0,0189 * \\
0.0001 \\
\end{array}$ & $\begin{array}{r}-0,0484 * \\
0.0000 \\
\end{array}$ & $\begin{array}{r}0,2240^{*} \\
0.0000 \\
\end{array}$ & $\begin{array}{r}-0,0233^{*} \\
0.0004 \\
\end{array}$ & $\begin{array}{r}0,1300^{*} \\
0.0000 \\
\end{array}$ & $\begin{array}{r}-0,0942 * \\
0.0000 \\
\end{array}$ & $\begin{array}{r}-0,0324 * * \\
0.0067 \\
\end{array}$ & $\begin{array}{r}0,1209^{*} \\
0.0000 \\
\end{array}$ \\
\hline $\mathrm{D}(\operatorname{REER}(-2))$ & $\begin{array}{r}0,0507 * \\
0.0000 \\
\end{array}$ & $\begin{array}{r}0,2380^{*} \\
0.0000 \\
\end{array}$ & $\begin{array}{r}0,1735^{*} \\
0.0000 \\
\end{array}$ & $\begin{array}{r}-0,0617 * \\
0.0000 \\
\end{array}$ & $\begin{array}{r}-0,1570^{*} \\
0.0000 \\
\end{array}$ & $\begin{array}{r}0,0225^{*} \\
0.0004 \\
\end{array}$ & $\begin{array}{r}-0,0421 * \\
0.0002 \\
\end{array}$ & $\begin{array}{r}-0,0503 * \\
0.0000 \\
\end{array}$ & $\begin{array}{r}-0,1151^{*} \\
0.0001 \\
\end{array}$ & $\begin{array}{r}-0,0444 * \\
0.0012 \\
\end{array}$ \\
\hline $\mathrm{D}(\operatorname{REER}(-3))$ & $\begin{array}{r}-0,0320 * \\
0.0000\end{array}$ & $\begin{array}{r}-0,0995^{*} \\
0.0000 \\
\end{array}$ & $\begin{array}{r}0,1147 * \\
0.0000 \\
\end{array}$ & $\begin{array}{r}0,0682^{*} \\
0.0000\end{array}$ & $\begin{array}{r}-0,1032 * \\
0.0001\end{array}$ & $\begin{array}{r}-0,0595^{*} \\
0.0000\end{array}$ & $\begin{array}{r}0,3073^{*} \\
0.0000\end{array}$ & $\begin{array}{r}0,0183 * \\
0.0000\end{array}$ & $\begin{array}{r}-0,2210^{*} \\
0.0000\end{array}$ & $\begin{array}{r}-0,2330 * \\
0.0000\end{array}$ \\
\hline $\mathrm{D}(\operatorname{REER}(-4))$ & $\begin{array}{r}0,0241 * \\
0.0000\end{array}$ & $\begin{array}{r}-0,0658^{*} \\
0.0001\end{array}$ & $\begin{array}{r}0,0315^{*} \\
0.0000\end{array}$ & $\begin{array}{r}0,0359 * \\
0.0000\end{array}$ & $\begin{array}{r}-0,0713^{*} \\
0.0001\end{array}$ & $\begin{array}{r}-0,0779^{*} \\
0.0000\end{array}$ & $\begin{array}{r}0,1318 * \\
0.0000\end{array}$ & $\begin{array}{r}0,0487 * \\
0.0000\end{array}$ & $\begin{array}{r}-0,1678^{*} \\
0.0001\end{array}$ & $\begin{array}{r}-0,3618^{*} \\
0.0000\end{array}$ \\
\hline $\mathrm{D}(\mathrm{TO})$ & $\begin{array}{r}0,3831^{*} \\
0.0000 \\
\end{array}$ & $\begin{array}{r}0,9490 * \\
0.0000\end{array}$ & $\begin{array}{r}0,5730 * \\
0.0000\end{array}$ & $\begin{array}{r}-0,0801 * \\
0.0000\end{array}$ & $\begin{array}{r}-0,2718 * * \\
0.0018\end{array}$ & $\begin{array}{r}-0,3654^{*} \\
0.0000\end{array}$ & $\begin{array}{r}0,0637 * \\
0.0000\end{array}$ & $\begin{array}{r}0,1784^{*} \\
0.0000\end{array}$ & $\begin{array}{r}0,0901^{*} \\
0.0000\end{array}$ & $\begin{array}{r}0,5458^{*} \\
0.0000\end{array}$ \\
\hline $\mathrm{D}(\mathrm{TO}(-1))$ & $\begin{array}{r}0,2758^{*} \\
0.0000 \\
\end{array}$ & $\begin{array}{r}0,4195^{*} \\
0.0002 \\
\end{array}$ & $\begin{array}{r}0,1704 * \\
0.0002 \\
\end{array}$ & $\begin{array}{r}-0,0151^{*} \\
0.0002 \\
\end{array}$ & $\begin{array}{r}0,8428 * \\
0.0001 \\
\end{array}$ & $\begin{array}{r}-0,2279 * \\
0.0001 \\
\end{array}$ & $\begin{array}{r}0,0970^{*} \\
0.0000 \\
\end{array}$ & $\begin{array}{r}-0,1569 * \\
0.0000 \\
\end{array}$ & $\begin{array}{r}0,0501 * \\
0.0001 \\
\end{array}$ & $\begin{array}{r}0,1132 * \\
0.0002 \\
\end{array}$ \\
\hline $\mathrm{D}(\mathrm{TO}(-2))$ & $\begin{array}{r}0,1876^{*} \\
0.0000 \\
\end{array}$ & $\begin{array}{r}0,3320 * \\
0.0001 \\
\end{array}$ & $\begin{array}{r}0,5559 * \\
0.0000 \\
\end{array}$ & $\begin{array}{r}-0,0695 * \\
0.0000 \\
\end{array}$ & $\begin{array}{r}0,0681 * * \\
0.0467 \\
\end{array}$ & $\begin{array}{r}-0,0475^{*} \\
0.0003 \\
\end{array}$ & $\begin{array}{r}-0,0916^{*} \\
0.0000 \\
\end{array}$ & $\begin{array}{r}-0,0156^{*} \\
0.0014 \\
\end{array}$ & $\begin{array}{r}0,1312 * \\
0.0000 \\
\end{array}$ & $\begin{array}{r}0,1157 * \\
0.0009 \\
\end{array}$ \\
\hline $\mathrm{D}(\mathrm{TO}(-3))$ & $\begin{array}{r}0,3486^{*} \\
0.0000\end{array}$ & $\begin{array}{r}-0,1008^{*} \\
0.0007\end{array}$ & $\begin{array}{r}1,0712 * \\
0.0000\end{array}$ & $\begin{array}{r}0,3042^{*} \\
0.0000\end{array}$ & $\begin{array}{r}-0,5815^{*} \\
0.0004\end{array}$ & $\begin{array}{r}-0,0129 * * \\
0.0278\end{array}$ & $\begin{array}{r}0,1109^{*} \\
0.0000\end{array}$ & $\begin{array}{r}0,1049^{*} \\
0.0000\end{array}$ & $\begin{array}{r}-0,0266^{*} \\
0.0001\end{array}$ & $\begin{array}{r}0,4359^{*} \\
0.0000\end{array}$ \\
\hline $\mathrm{D}(\mathrm{TO}(-4))$ & $\begin{array}{r}0,0650^{*} \\
0.0003\end{array}$ & $\begin{array}{r}-0,2858^{*} \\
0.0000\end{array}$ & $\begin{array}{r}0,6636^{*} \\
0.0004\end{array}$ & $\begin{array}{r}0,0737 * \\
0.0000\end{array}$ & $\begin{array}{r}0,4628^{*} \\
0.0000\end{array}$ & $\begin{array}{r}-0,1305^{*} \\
0.0001\end{array}$ & $\begin{array}{r}0,0310^{*} \\
0.0001\end{array}$ & $\begin{array}{r}-0,0424 * \\
0.0001\end{array}$ & $\begin{array}{r}0,086 * 9 \\
0.0001\end{array}$ & $\begin{array}{r}-0,2736^{*} \\
0.0004\end{array}$ \\
\hline $\mathrm{C}$ & $\begin{array}{r}-1,1827 * * \\
0.0160 \\
\end{array}$ & $\begin{array}{r}-0,6236 \\
0.4321 \\
\end{array}$ & $\begin{array}{r}-5,1622 * * \\
0.0197 \\
\end{array}$ & $\begin{array}{r}-0,0190 \\
0.9236 \\
\end{array}$ & $\begin{array}{l}0,3818 \\
0.8376 \\
\end{array}$ & $\begin{array}{r}-0,8037 * \\
0.0054 \\
\end{array}$ & $\begin{array}{r}5,5727 * * * * \\
0.0852 \\
\end{array}$ & $\begin{array}{r}0,3134 * \\
0.0008 \\
\end{array}$ & $\begin{array}{l}3,7600 \\
0.6577 \\
\end{array}$ & $\begin{array}{l}1,0007 \\
0.6798 \\
\end{array}$ \\
\hline
\end{tabular}

Notes:

i. Numbers in parentheses are p-values of t-statistics.

ii. $\quad * * *, * *$ and $*$ indicates $1 \%, 5 \%$ and $10 \%$ significance level respectively. 
Short run results for each country show that the established long run results for the panel hold for most of the countries except for Mexico and Indonesia. For Mexico speed of adjustment coefficient has a correct sign and negative but insignificant. On the other hand, for Indonesia it has a positive sign. The speed of adjustment coefficients for Thailand has the largest in absolute terms as opposed to the smallest value for Mexico. Most of the short run coefficients for all countries in the sample are significant.

After estimating the short and the long run effects and finding the long run relationship among the variables, we implemented Dumitrescu Hurlin panel granger causality test to find the direction of causality between the variables and the results of the causality test are displayed in Table 9 .

Table 9. Dumitrescu Hurlin Panel Granger Causality Test Results

\begin{tabular}{|c|c|c|c|}
\hline Null Hypothesis & $\mathbf{W}^{\mathrm{HCN}}$ & $Z_{N T}^{H N C}$ & Prob \\
\hline FDIGDP $\nrightarrow$ GDPGROWTH & 2.43482 & -0.86803 & 0.3854 \\
\hline GDPGROWTH $\nrightarrow$ FDIGDP & 6.92652 & 4.03040 & 6.E-05* \\
\hline GFCFGDP $\nrightarrow$ GDPGROWTH & 5.46030 & 2.43142 & $0.0150 * *$ \\
\hline GDPGROWTH $\nrightarrow$ GFCFGDP & 8.28397 & 5.51077 & 4.E-08* \\
\hline REER $\nrightarrow$ GDPGROWTH & 4.99729 & 1.92648 & $0.0540 * *$ \\
\hline GDPGROWTH $\nrightarrow$ REER & 4.45578 & 1.33594 & 0.1816 \\
\hline TO $\nrightarrow$ GDPGROWTH & 4.34967 & 1.22022 & 0.2224 \\
\hline GDPGROWTH $\nrightarrow$ TO & 4.80026 & 1.71161 & $0.0870 * * *$ \\
\hline GFCFGDP $\nrightarrow$ FDIGDP & 7.30607 & 4.44433 & 9.E-06* \\
\hline FDIGDP $\nrightarrow$ GFCFGDP & 2.78571 & -0.48536 & 0.6274 \\
\hline REER $\nrightarrow$ FDIGDP & 7.61691 & 4.78332 & 2.E-06* \\
\hline FDIGDP $\nrightarrow$ REER & 3.73338 & 0.54812 & 0.5836 \\
\hline TO $\nrightarrow$ FDIGDP & 6.35002 & 3.40171 & $0.0007^{*}$ \\
\hline FDIGDP $\nrightarrow$ TO & 6.14137 & 3.17417 & $0.0015^{*}$ \\
\hline REER $\nrightarrow$ GFCFGDP & 4.15739 & 1.01052 & 0.3122 \\
\hline GFCFGDP $\nrightarrow$ REER & 5.09016 & 2.02777 & $0.0426 * *$ \\
\hline TO $\nrightarrow$ GFCFGDP & 6.32138 & 3.37047 & $0.0008 *$ \\
\hline GFCFGDP $\nrightarrow$ TO & 4.72556 & 1.63015 & $0.1011 * * *$ \\
\hline TO $\nrightarrow$ REER & 5.24754 & 2.19939 & $0.0278^{* *}$ \\
\hline REER $\nrightarrow$ TO & 4.51419 & 1.39963 & 0.1616 \\
\hline
\end{tabular}

According to the results presented in Table 9, there is a uni-directional causality running from GDP growth to FDIGDP ratio. Also, there is a feedback between GDP growth and GFCFGDP ratio. While REER cause to GDP growth, the GDP growth causes TO unidirectionally. 
When we examine the results of the causalities among the independent variables, we can conclude that GFCFGDP granger causes FDIGDP and REER. Also, there is a feedback between GFCFGDP and TO. REER granger cause FDIGDP and TO granger causes REER unidirectionally. Moreover, there are feedbacks between TO and FDIGDP and GFCFGDP.

\section{CONCLUSION}

This study investigates the effects of FDI to GDP ratio, GFCF to GDP ratio, real exchange rate, and trade openness GDP ratio on economic growth in NICs by using panel data for 1982 and 2019. We used the panel ARDL model and Dumitrescu Hurlin panel granger causality test to analyze the relationship between economic growth and the other variables.

The study results show a statistically significant relation between economic growth and FDI, gross capital formation, and real exchange rate. On the other hand, results also yield a negative significant long-run relation between economic growth and trade openness. Short-run results of the countries support these findings except for Mexico and Indonesia.

Considering that NICs continue to reach developed country status, the study results have several implications for these countries. First of all, to keep growing, they need to encourage more FDI, increase their capital stock, and enhance their external competitiveness. However, it is also the fact that most of these countries are heavily import-dependent countries. To overcome the negative effect of trade openness on their economic growth, they have to produce import substitutes and encourage more industrial exports. The best way to become a strong competitor in international trade is to understand that they have to develop their technologies and produce high value-added products. That requires adaptation of a new industrial policy supported by exchange rate policy, monetary policy, education system, and countries' institutional quality. The study can be replicated by using different country groups and alternative methods such as MG and Dynamic Fixed Effects.

\section{REFERENCES}

Asghar, N., \& Hussain, Z. (2014) "Financial development, trade openness and economic growth in developing countries: Recent evidence from panel data". Pakistan Economic and Social Review, 99-126.

Adhikary, B. K. (2011) "FDI, trade openness, capital formation, and economic growth in Bangladesh: a linkage analysis”. International Journal of Business and Management, 6(1), 16. 
Bibi, S., Ahmad, S. T., \& Rashid, H. (2014) "Impact of trade openness, FDI, exchange rate and inflation on economic growth: A case study of Pakistan". International Journal of Accounting and Financial Reporting, 4(2), 236.

Breusch, T. S. and Pagan, A. R. (1980) "The lagrange multiplier test and its applications to model specificationin econometrics". Review of Economic Studies, 47: 239-253.

Engle, R. F. and Granger, C. W. J. (1987) "Cointegration and error correction: Representation, estimation and testing", Econometrica, 55, 251-76.

Haque, S., \& Amin, S. B. (2018) "Foreign direct investment, trade openness and economic growth: The case of Bangladesh". World Review of Business Research, 8(3), 104-125.

Im, K. S., Pesaran, M. H., \& Shin, Y. (2003) "Testing for unit roots in heterogeneous panels". Journal of econometrics, 115(1), 53-74.

Klasra, M. A. (2011) "Foreign direct investment, trade openness and economic growth in Pakistan and Turkey: An investigation using bounds test”. Quality \& Quantity, 45(1), 223-231.

Makki, S. S., \& Somwaru, A. (2004) "Impact of foreign direct investment and trade on economic growth: Evidence from developing countries”. American journal of agricultural economics, 86(3), 795-801

Nketiah, E., Cai, X., Adjei, M., \& Boamah, B. B. (2019) "Foreign direct investment, trade openness and economic growth: Evidence from Ghana”. Open Journal of Business and Management, 8(01), 39.

Olabisi, O. E., \& Lau, E. (2018) “Causality Testing between Trade Openness, Foreign Direct Investment and Economic Growth: Fresh Evidence from Sub-Saharan African Countries". Economia Internazionale/International Economics, 71(4), 437-464.

Pesaran, M.H. (2004) “General Diagnostic Tests for Cross Section Dependence in Panels”.

Pesaran, M. H. (2007) “A simple panel unit root test in the presence of cross-section dependence". Journal of applied econometrics, 22(2), 265-312.

Pesaran, M. H., Shin, Y., \& Smith, R. P. (1997) "Pooled estimation of long-run relationships in dynamic heterogeneous panels".

Pesaran, M.H., Ullah, A. and Yamagata, T. (2008). A bias-adjusted LM test of error cross section independence. Econometrics Journal, 11, pp.105-127.

Pradhan, R. P., Bagchi, T. P., Chowdhury, K., \& Norman, N. R. (2012) "Growth, foreign investment and trade-openness interactions in ten OECD countries: a panel-VAR approach". International Journal of Banking, Accounting and Finance, 4(4), 273-293. 
Pradhan, R. P., Arvin, M. B., Hall, J. H., \& Nair, M. (2017) “Trade openness, foreign direct investment, and finance-growth nexus in the Eurozone countries". The Journal of International Trade \& Economic Development, 26(3), 336-360.

Westerlund, J. (2007) "Testing for error correction in panel data". Oxford Bulletin of Economics and statistics, 69(6), 709-748.

Wiredu, J., Nketiah, E., \& Adjei, M. (2020) "The relationship between trade openness, foreign direct investment and economic growth in West Africa: Static panel data model". Journal of Human Resource and Sustainability Studies, 8(1), 18-34.

Yusoff, M. B., \& Febrina, I. (2014) “Trade openness, real exchange rate, gross domestic investment and growth in Indonesia". Margin: The Journal of Applied Economic Research, 8(1), 1-13.

Yusoff, M. B., \& Nuh, R. (2015) "Foreign direct investment, trade openness and economic growth: Empirical evidence from Thailand". Foreign Trade Review, 50(2), 73-84.

World Trade Statistical Review

https://www.wto.org/english/res_e/statis_e/wts2020_e/wts2020_e.pdf

\begin{tabular}{|c|c|c|}
\hline $\begin{array}{c}\text { KATKI ORANI / } \\
\text { CONTRIBUTION RATE }\end{array}$ & $\begin{array}{l}\text { AÇIKLAMA / } \\
\text { EXPLANATION }\end{array}$ & $\begin{array}{c}\text { KATKIDA } \\
\text { BULUNANLAR / } \\
\text { CONTRIBUTORS } \\
\end{array}$ \\
\hline $\begin{array}{c}\text { Fikir veya Kavram / Idea } \\
\text { or Notion }\end{array}$ & $\begin{array}{l}\text { Araştırma hipotezini veya } \\
\text { fikrini oluşturmak / Form the } \\
\text { research hypothesis or idea }\end{array}$ & $\begin{array}{c}\text { Asst. Prof. Sevilay } \\
\text { KÜÇÜKSAKARYA (Ph.D.) } \\
\text { Prof. Mustafa ÖZER (Ph.D.) }\end{array}$ \\
\hline Tasarım / Design & $\begin{array}{l}\text { Yöntemi, ölçeği ve deseni } \\
\text { tasarlamak / Designing } \\
\text { method, scale and pattern }\end{array}$ & $\begin{array}{c}\text { Asst. Prof. Sevilay } \\
\text { KÜÇÜKSAKARYA (Ph.D.) } \\
\text { Prof. Mustafa ÖZER (Ph.D.) }\end{array}$ \\
\hline $\begin{array}{l}\text { Veri Toplama ve İşleme / } \\
\text { Data Collecting and } \\
\text { Processing }\end{array}$ & $\begin{array}{c}\text { Verileri toplamak, } \\
\text { düzenlenmek ve raporlamak / } \\
\text { Collecting, organizing and } \\
\text { reporting data }\end{array}$ & $\begin{array}{c}\text { Asst. Prof. Sevilay } \\
\text { KÜÇÜKSAKARYA (Ph.D.) } \\
\text { Prof. Mustafa ÖZER (Ph.D.) }\end{array}$ \\
\hline $\begin{array}{l}\text { Tartişma ve Yorum / } \\
\text { Discussion and } \\
\text { Interpretation }\end{array}$ & $\begin{array}{c}\text { Bulguların } \\
\text { değerlendirilmesinde ve } \\
\text { sonuçlandırılmasında } \\
\text { sorumluluk almak / Taking } \\
\text { responsibility in evaluating } \\
\text { and finalizing the findings }\end{array}$ & $\begin{array}{c}\text { Asst. Prof. Sevilay } \\
\text { KÜÇÜKSAKARYA (Ph.D.) } \\
\text { Prof. Mustafa ÖZER (Ph.D.) }\end{array}$ \\
\hline $\begin{array}{l}\text { Literatür Taramas1 / } \\
\text { Literature Review }\end{array}$ & $\begin{array}{c}\text { Çalışma için gerekli literatürü } \\
\text { taramak / Review the } \\
\text { literature required for the } \\
\text { study }\end{array}$ & $\begin{array}{c}\text { Asst. Prof. Sevilay } \\
\text { KÜÇÜKSAKARYA (Ph.D.) } \\
\text { Prof. Mustafa ÖZER (Ph.D.) }\end{array}$ \\
\hline
\end{tabular}


Hakem Değerlendirmesi: Dış bağımsız.

Çıkar Çatışması: Yazar(lar) çıkar çatışması bildirmemiştir.

Finansal Destek: Yazar(lar) bu çalışma için finansal destek almadığını beyan etmiştir.

Teşekkür: -

Peer-review: Externally peer-reviewed.

Conflict of Interest: The author(s) has/have no conflict of interest to declare.

Grant Support: The author(s) declared that this study has received no financial support.

Acknowledgement: 